\title{
Inhibition of ALA-PDT on A431 cells in cutaneous squamous cell carcinoma
}

\author{
Xin Zhang ${ }^{1,2}$, Yuqin Hao*2 \\ ${ }^{1}$ Department of Dermatology, The Third Affiliated Hospital, Baotou, China \\ ${ }^{2}$ Inner Mongolia Medical University, Hohhot, China
}

Received: February 26, 2017

DOI: $10.14725 /$ dcc.v4n2p6
Accepted: April 6, $2017 \quad$ Online Published: June 10, 2017

URL: http://dx.doi.org/10.14725/dcc.v4n2p6

\begin{abstract}
Objective: To determine the optimal dose of ALA-PDT on the inhibition of A431 cells proliferation in cutaneous squamous cell carcinoma.

Methods: A431 cells were cultured firstly in vitro, and then, were treated with different drug concentrations $(0.5,1$ and 2 $\mathrm{mmol} / \mathrm{L})$ and different doses of PDT $\left(5,10,20,40 \mathrm{~J} / \mathrm{cm}^{2}\right)$. The proliferation of treated A431 cells was detected by MTT.

Results: The inhibition rates of ALA-PDT on A431 cells treated under the condition of $0.5 \mathrm{mmol} / \mathrm{L}$ ALA combined with 5, 10, 20 and $40 \mathrm{~J} / \mathrm{cm}^{2}$ PDT were $6 \%, 10 \%, 15 \%$ and $18 \%$ respectively. The inhibition rates of ALA-PDT on A431 cells treated with $1 \mathrm{mmol} / \mathrm{L}$ ALA combined with PDT of 5, 10, 20 and $40 \mathrm{~J} / \mathrm{cm}^{2}$ were $30 \%, 52 \%, 80 \%$ and $82 \%$ respectively. The inhibition rates of ALA-PDT on A431 cells treated with $2 \mathrm{mmol} / \mathrm{L}$ ALA combined with 5, 10, 20 and $40 \mathrm{~J} / \mathrm{cm}^{2}$ PDT were $31 \%, 54 \%, 81 \%$ and $82 \%$ respectively.

Conclusions: The highest inhibition rate of PDT on A431 cell proliferation can be acquired under the condition of $1 \mathrm{mmol} / \mathrm{L}$ ALA and $20 \mathrm{~J} / \mathrm{cm}^{2}$ PDT.
\end{abstract}

Key Words: ALA-PDT, Cutaneous squamous cell carcinoma, A431 cell, Proliferation

Squamous cell carcinoma (SCC) is a common malignant tumor among various skin cancers, with the morbidity going up year by year. A considerable amount of therapies can be used in the treatment of SCC. ALA-PDT is a new therapy which has been highly developed in the recent 20 years since some traditional therapies (e.g. surgery, radiotherapy, chemotherapy etc.). Based on the phototoxic reaction of photosensitizers, it is a new therapy that photosensitizers are activated by light to generate reactive oxygen species, and then result in cell damage even death. ${ }^{[1]}$ ALA-PDT has made remarkable achievements in the clinical treatment of tumors. The most prominent advantage of ALA-PDT is to accurately locate target tissues and selectively kill tumor cells with less affects on adjacent normal tissues. PDT is less invasive and less toxic than traditional therapies (such as surgery, chemotherapy, radiotherapy etc.), and it also has a cosmetic effect as an irreplaceable benefit in the treatment of tumors. $^{[2,3]}$ In view of basic researches, scholars have their differences in the effective dose of ALA-PDT in their experimental studies, although ALA-PDT has been used in the clinical application. Therefore, different concentrations of ALA and different doses of PDT were applied to this experiment for observing the effect of ALA-PDT on A431 cells in squamous carcinoma, in order that it can provide the experimental evidence for the application of ALA-PDT to basic researches (such as cytology etc.).

*Correspondence: Yuqin Hao; E-mail: haoyuqin0472@163.com; Address: Department of Dermatology, The Third Affiliated Hospital, Inner Mongolia Medical University, Baotou, China. 


\section{Materials and methods}

\subsection{Instruments and reagents}

Experimental instruments and reagents: ALA was produced by Sigma; Fetal bovine serum (FBS), DMEM High Glucose Medium and pancreatin were products of Invitrogen; MTT was manufactured by Sigma; 96-well reaction plates were products of Roche from Germany; Microplate reader was made by Thermo Labsystems; Red light therapy device was produced by Lifotronic.

\subsection{Cell culture}

Human cutaneous squamous cell carcinoma A431 cell strains (provided by Changsha Yingrun Biotechnology Co., Ltd.) were adherently cultured in DMEM (High Glucose) complete medium (containing 10\% fetal bovine serum, 100 $\mathrm{U} / \mathrm{mL}$ penicillin and $100 \mu \mathrm{g} / \mathrm{mL}$ streptomycin), and placed into an incubator (condition: $37^{\circ} \mathrm{C}$, saturated humidity and $5 \% \mathrm{CO}^{2}$ ). The medium was replaced every day or every two days. Cells proliferated adherently in monolayer until covering the bottom of the cell culture flask, they would be digested by trypsin solution into individual cells. Cells in the logarithmic phase were taken and prepared for the experiment.

\subsection{Experiment grouping}

No-treatment control group: no photosensitizers and no light irradiation; Light control group: only light irradiation, no photosensitizers; Drug control group: only photosensitizers, no light irradiation; ALA-PDT group: different concentrations of ALA + different light doses of PDT.

\subsection{PDT treatment on cells}

A431 cells in a good state and in the logarithmic phase were taken and inoculated in 96-well cell culture plates with a seeding density of $10^{4}$ cells/well, the volume of medium in each well was $200 \mu \mathrm{L}$. After A431 cells were adherent for 24 hours, the above-mentioned intervention should be made to these groups. The concentrations of ALA respectively were: $0,0.5,1$ and $2 \mathrm{mmol} / \mathrm{L}$; ALA light-proof incubation time was $4 \mathrm{~h}$; the condition of light irradiation was as follows: a red light therapy device (wave length $635 \mathrm{~nm}$, lighting power density $18 \mathrm{~mW} / \mathrm{cm}^{2}$ ) was applied to the vertical irradiation with light spot set at a distance of $5 \mathrm{~cm}$ from the 96-well culture plate, and the experimental cells were covered completely by the therapeutic light spot with the irradiation power density of $5,10,20$ and $40 \mathrm{~J} / \mathrm{cm}^{2}$ respectively. Drug control group: ALA $1 \mathrm{mmol} / \mathrm{L}$, strictly lightproof. After intervention, it was required to replace with fresh medium immediately and continue incubating for 24 hours, and then prepare for MTT assay. Each group was made in triplicate, and the experiment was made three times.

\subsection{MTT assay of cell proliferation in vitro}

At each measurement time point, $20 \mu \mathrm{L}$ of MTT solution (5 $\mathrm{mg} / \mathrm{mL}$ ) was added to each well containing cells (of each group), which were cultured in the incubator $\left(37^{\circ} \mathrm{C}, 5 \%\right.$ $\mathrm{CO}^{2}$ for 4 hours. Culture supernatant was sucked and abandoned carefully in order to avoid sucking up purple crystals.

$150 \mu \mathrm{l}$ of DMSO was added to each well. After oscillation for 10 minutes, crystals were dissolved completely.

The microplate reader $(490 \mathrm{~nm})$ was used to measure the value of optical density (OD) in each well. After recording results, the group with no drug addition was taken as no-treatment control group to calculate inhibition rate of cell proliferation/survival rate: inhibition rate (IP, \%) $=(1$ - OD of treatment group/OD of no-treatment control group) $\times 100 \%$; survival rate $=$ OD of treatment group/OD of notreatment control group $\times 100 \%$. The survival rate of notreatment control group was $100 \%$.

\subsection{Statistical methods}

SPSS 20.0 statistical software was applied to the statistical treatment. All data were represented by mean \pm standard deviation with the application of ANOVA; the difference ( $p$ $<.05$ ) was of statistical significance.

\section{Results}

\subsection{Only light irradiation and only photosensitizers}

Only light irradiation and only photosensitizers had no inhibitory effect on cell proliferation.

\subsection{Inhibitory effects of different concentrations of ALA and different light doses of PDT on the proliferation of A431 cells}

The inhibition rates of ALA-PDT on A431 cells treated under the condition of $0.5 \mathrm{mmol} / \mathrm{L}$ ALA combined with 5, 10,20 and $40 \mathrm{~J} / \mathrm{cm}^{2}$ PDT were $6 \%, 10 \%, 15 \%$ and $18 \%$ respectively; the inhibition rates of ALA-PDT on A431 cells treated with $1 \mathrm{mmol} / \mathrm{L}$ ALA combined with PDT of $5,10,20$ and $40 \mathrm{~J} / \mathrm{cm}^{2}$ were $30 \%, 52 \%, 80 \%$ and $82 \%$ respectively; the inhibition rates of ALA-PDT on A431 cells treated with $2 \mathrm{mmol} / \mathrm{L}$ ALA combined with 5, 10, 20 and $40 \mathrm{~J} / \mathrm{cm}^{2}$ PDT were $31 \%, 54 \%, 81 \%$ and $82 \%$ (see Table 1 and Figure 1). 
Table 1: Inhibitory effects of different concentrations of ALA and different light doses of PDT on A431 cells

\begin{tabular}{lllllllll}
\hline $\begin{array}{l}\text { ALA } \\
(\mathbf{m m o l} / \mathbf{L})\end{array}$ & $\mathbf{5 ~ J / \mathbf { c m } ^ { 2 } \text { OD }}$ & PIR (\%) & $\mathbf{1 0 ~ J / \mathbf { c m } ^ { 2 } \text { OD }}$ & PIR (\%) & $\mathbf{2 0 ~ J / \mathbf { c m } ^ { 2 } \text { OD }}$ & PIR (\%) & 40 J/cm $\mathbf{~ O D ~}^{2}$ & PIR (\%) \\
\hline 0 & $0.736 \pm 0.004$ & $0.710 \pm 0.008$ & 0 & $0.702 \pm 0.006$ & 0 & $0.690 \pm 0.003$ & 0 \\
0.5 & $0.692 \pm 0.006$ & $6.02 \pm 1.42^{*}$ & $0.639 \pm 0.011$ & $10.07 \pm 1.48^{*}$ & $0.597 \pm 0.014$ & $14.98 \pm 3.96^{*}$ & $0.566 \pm 0.017$ & $18.07 \pm 3.19^{*}$ \\
1 & $0.515 \pm 0.013$ & $30.27 \pm 2.58^{*}$ & $0.341 \pm 0.015$ & $52.38 \pm 2.77^{*}$ & $0.140 \pm 0.004$ & $80.36 \pm 4.10^{*}$ & $0.124 \pm 0.004$ & $81.97 \pm 3.31^{*}$ \\
2 & $0.500 \pm 0.011$ & $32.41 \pm 2.32^{*}$ & $0.284 \pm 0.005$ & $60.23 \pm 5.98^{*}$ & $0.112 \pm 0.008$ & $81.21 \pm 4.24^{*}$ & $0.097 \pm 0.004$ & $82.14 \pm 3.78^{*}$ \\
$F$ & & 131.106 & & 121.310 & & 257.639 & .000 & 347.335 \\
$p$ & .000 & & .000 & & & .000 \\
\hline
\end{tabular}

Note. ${ }^{*}$ In comparison with no-treatment control group, $p<.05$

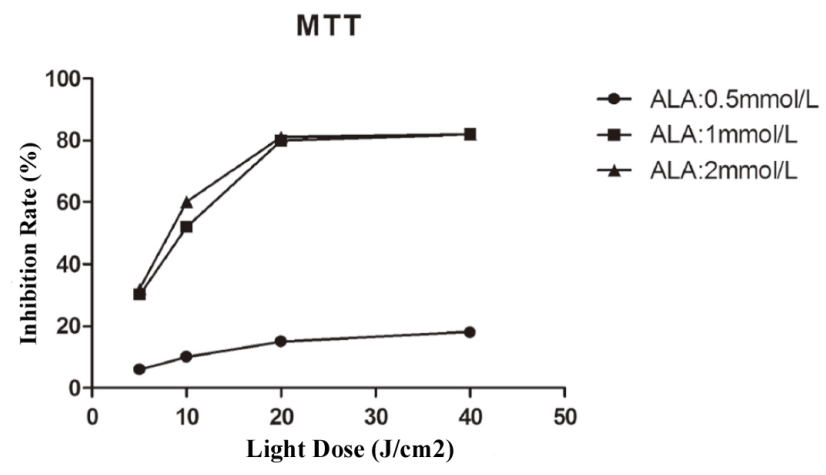

Figure 1: Inhibitory effects of different concentrations of ALA and different light doses of PDT on A431 cells

$1 \mathrm{mmol} / \mathrm{L}$ and $2 \mathrm{mmol} / \mathrm{L}$ ALA had a remarkably inhibitory effect on A431 cells, but there was no significant difference between them; the inhibition rate of ALA-PDT on A431 cells was improved with the light dose going up, but it almost kept stable between 20 and $40 \mathrm{~J} / \mathrm{cm}^{2}$.

\section{Discussion}

From the aspect of dermatology, SCC is a common malignant tumor with the morbidity increased gradually. Current therapies include surgical resection (Mohs surgery), cryotherapy, electrocautery, topical treatment (5fluorouracil and imiquimod), radiotherapy and so on. For large-area, special-part (facial, genitalia) and multi-focal lesions of SCC, these therapies are ineffective and easy to form scars. In addition, these therapies are too limited in terms of the cosmetic effect to meet the requirement for good appearance. PDT, which has sprung up and developed continuously in the recent 20 years, is a new technology in the treatment of tumors. It has made remarkable achievements in the clinical treatment of tumors. As it is easy to implement light irradiation on skin lesions, the application of PDT to the dermatologic area is a considerably active research topic. ${ }^{[-6]}$ As a new therapy, PDT is of good tissue selectivity to avoid destroying normal cells and free from the limitation of the position and size of skin damage. It has increasingly become a frequently used method in the clini- cal treatment of proliferative diseases (such as SCC).

In view of basic researches, researchers have their differences in the effective dose of ALA-PDT in their experiments, although ALA-PDT has been used in the clinical application. For example, in the experiment (inhibition of ALA-PDT on the proliferation of A431 cells in cutaneous squamous cell carcinoma) conducted by Qiao L et al., ${ }^{[7]}$ the condition was as follows: ALA $0.4 \mathrm{mg} / \mathrm{mL}$, lighting power density $10 \mathrm{~mW} / \mathrm{cm}^{2}$, irradiation power density $2.5 \mathrm{~J} / \mathrm{cm}^{2}$. Liu YY et al. ${ }^{[8]}$ found that the highest inhibition rate of ALA-PDT on A431 cell proliferation was with $3.2 \mathrm{mmol} / \mathrm{L}$ ALA and $80 \mathrm{~J} / \mathrm{cm}^{2}$ PDT. In the experiment (killing effect of ALA-PDT on SCL-1 cells in human cutaneous squamous cell carcinoma) conducted by Zhang XJ et al., ${ }^{[9]}$ the condition was as follows: ALA concentration $40 \mu \mathrm{g} / \mathrm{mL}$, lighting power density $230 \mathrm{~mW} / \mathrm{cm}^{2}$. Whereas, irradiation power density, lighting power density and light irradiation time are three parameters in the light irradiation, the conversion formula is: light irradiation time $(\mathrm{S})=$ irradiation power density $\left(\mathrm{J} / \mathrm{cm}^{2}\right) /$ lighting power density $\left(\mathrm{W} / \mathrm{cm}^{2}\right)$.

Different concentrations of ALA and different doses of PDT were applied to this experiment for observing the inhibitory effect of ALA-PDT on A431 cells in squamous cell carcinoma, in order that it can provide the experimental dosage evidence for the application of ALA-PDT to basic researches (such as cytology etc.). To determine the optimal effective dose of ALA-PDT on the inhibition of cell proliferation in human cutaneous squamous cell carcinoma, MTT assay was applied to this experiment. It was found that only photosensitizers and only light irradiation had no effect on cell growth. At the same incubation time and ALA concentration, the inhibition rate of ALA-PDT on cells was improved with the light dose going up, but it almost kept stable between 20 and $40 \mathrm{~J} / \mathrm{cm}^{2}$. The inhibition rates of ALA-PDT on cells in each group under the condition of $20-40 \mathrm{~J} / \mathrm{cm}^{2}$ had no significant difference (all $p>.05$ ), and the killing effect turned out to be steady. It was indicated that a higher light dose of PDT didn't always mean a stronger killing effect on cells. At the same incubation time and light dose, different light doses had a significant difference in the inhibition rate of ALA-PDT on A431 cells under the ALA concentrations of $1 \mathrm{mmol} / \mathrm{L}$ and $2 \mathrm{mmol} / \mathrm{L}$ in comparison with 
$0.5 \mathrm{mmol} / \mathrm{L}$ (all $p<.05$ ). However, different light doses had no significant difference in the inhibition rate between $1 \mathrm{mmol} / \mathrm{L}$ and $2 \mathrm{mmol} / \mathrm{L}$ (all $p>.05$ ).

The experimental results showed that, for human cutaneous squamous cell carcinoma A431 cells cultured in vitro, the inhibition rate was $52 \%$ with A431 cells treated under the condition of $1 \mathrm{mmol} / \mathrm{L}$ ALA combined with $10 \mathrm{~J} / \mathrm{cm}^{2}$ PDT;

\section{References}

[1] Darlenski R, Fluhr JW. Photodynamic therapy in dermatology: past, present, and future. J Biomed Opt. 2013; 18(6): 1208.

[2] Lee Y, Baron ED. Photodynamic therapy: current evidence and applications in dermatology. Sem in Cutan Med Surg. 2011; 30(4): 199-209. PMid: 22123417. https://doi.org/10.1016/ j.sder.2011.08.001

[3] Shirasu N, Nam SO, Kuroki M. Tumor-targeted photodynamic therapy. Anticancer Res. 2013; 33(7): 2823-2831. PMid: 23780966.

[4] Qing YG, Zhang XP, Li J, et al. Photodynamic therapy for malignant and non-malignant diseases: clinical investigation and application. Chin Med J (Engl). 2006; 119(10): 845-857.

[5] Braathen LR, Szeimies RM, Basset-Seguin N, et al. Guidelines on the use of photodynamic therapy for nonmelanoma sin cancer: an international consensus. International society for photody- the inhibition rate was $82 \%$ with $\mathrm{A} 431$ treated under the condition of $1 \mathrm{mmol} / \mathrm{L}$ ALA and $20 \mathrm{~J} / \mathrm{cm}^{2}$ PDT, the killing effect of ALA-PDT was optimal.

\section{Conflicts of Interest Disclosure}

The authors have no conflicts of interest related to this article.

namic therapy in dermatology, 2005. J Am Acad Dermatol. 2007; 56(1): 125-143. PMid: 17190630. https://doi.org/10.1016/ j.jaad.2006.06.006

[6] MacCormack MA. Photodynamic therapy in dermatology: an update on applications and outcomes. Semin Cutan Medsurg. 2008; 27(1): 52-62. PMid: 18486025. https://doi.org/10.1016/j . sder.2007.12.001

[7] Qiao L, Yang ZY, Xu CS et al. Effect of photodynamic therapy on the proliferation and cell cycle of human squamous carcinoma A431 cells. Journal of Shanxi Medical University. 2016; 47(1): 51-54.

[8] Liu YY, Wang YF, Zhang CM et al. Effects of ALA-PDT on Caspase-3 and Caspase-7 expressions in cutaneous squamous cell carcinoma A431 cells. Journal of Shandong University. 2014; 52(12): 50-53.

[9] Zhang XJ, Jiao YN, Liu JP, et al. The Effect of Extracellular Signalregulated Kinase (ERK 1/2) in ALA-PDT Killing SCL-1 Cell. The Chinese Journal of Dermatovenereology. 2013; 27(5): 435-439. 